\title{
COMPARATIVE ASSESSMENT OF HUMAN INTERNAL ORGANS WITH BMI AMONGST ADULT POPULATION IN BENGAL
}

\author{
Partha Bhattacharya ${ }^{1}$, Rina Das², Somnath Das ${ }^{3}$
}

${ }^{1}$ Associate Professor, Department of Forensic Medicine and Toxicology, RG Kar Medical College, Kolkata, West Bengal, India. ${ }^{2}$ Assistant Professor, Department of Forensic Medicine and Toxicology, RG Kar Medical College, Kolkata, West Bengal, India. 3Professor, Department of Forensic Medicine and Toxicology, RG Kar Medical College, Kolkata, West Bengal, India. \begin{abstract}
BACKGROUND

The organ weight is one of the important criteria used by pathologist during autopsy to detect any abnormality comparing the normal weight of that specific organ. But no such standard values of normal weights of internal organs are readily available for that of Indian population.

This present study is an attempt to find out data of Bengali population with respect to their organ weights, its sexual dimorphism and its relation with the BMI.
\end{abstract}

\section{MATERIALS AND METHODS}

It is a descriptive study. The randomly selected group was between 18 and 60 years of age from the bodies coming for autopsy at RG Kar Medical College Mortuary, Kolkata.

\section{RESULTS}

In the study the mean weight of brain, heart, liver and spleen of Bengali males were 1.215, 0.291, 1.280 and $0.103 \mathrm{~kg}$ respectively. Whereas, the mean weight of brain, heart, liver and spleen of Bengali females were 1.098, 0.273, 1.076 and $0.091 \mathrm{~kg}$ respectively. All these values showed a definite sexual dimorphism among the population. Significant values were obtained only among the median weights of heart, liver and spleen compared with different categories of BMI among the Bengali males and not among the Bengali females. Non-parametric correlation test of BMI vs. internal organs showed positive correlation for all internal organs with BMI, but the values were significantly strong only with the heart, liver and spleen of the Bengali males.

\section{CONCLUSION}

This study has unambiguously proved that the organ weights in case of males are significantly more than that of females. It is in favour that BMI has a positive correlation with internal organ weight, especially in case of males.

\section{KEY WORDS}

Bengali Population, BMI, Correlation, Internal Organ Weight.

HOW TO CITE THIS ARTICLE: Bhattacharya P, Das R, Das S. Comparative assessment of human internal organs with BMI amongst adult population in Bengal. J. Evolution Med. Dent. Sci. 2018;7(23):2789-2792, DOI: 10.14260/jemds/2018/629

\section{BACKGROUND}

Human organs/ organ system plays a significant role in almost all branches of medical sciences including Forensic Medicine, as any deviation from organ weight from normal range suggests presence of some pathology in the organs, thus guiding in determination of the cause of death.(1,2) During autopsy, pathologist examines the organs and considers whether they are showing any pathological changes or not. The organ weight is one of the important criteria used by pathologist during autopsy to detect any abnormality comparing the normal weight of that specific organ.

Different organs' weight has significant potential clinical value in relation to underlying pathology. For example, weight of heart is increased in atherosclerotic disease, especially in old age groups. Liver volumes are not only important in determining disease state and disease progression, but in

'Financial or Other Competing Interest': None.

Submission 27-04-2018, Peer Review 20-05-2018,

Acceptance 27-05-2018, Published 04-06-2018.

Corresponding Author:

Dr. Rina Das,

56A/34, Banerjee Para Road,

SBI Housing Complex, Plot 97,

Kolkata-700041, West Bengal.

E-mail: somnath1976@rediffmail.com

DOI: $10.14260 /$ jemds $/ 2018 / 629$

\section{(c) $(1) \ominus$}

estimating segmental liver volumes for transplant donors and planning the extent of hepatectomy in cancer patients.(3)

Several standard textbooks that show normal internal organs weight (IOW), but all of these are referenced from foreign countries. $(4,5)$ Very few literatures are available on this subject for the population of India in general $(6,7,8)$ and West Bengal region in particular.(9) Being resident of Bengal, we are dealing mainly with Bengali population and there are no such standard values of normal weights of internal organs available for these strata of Indian population. This present study is an attempt to find out data of Bengali population, which may differ from the available data of country as a whole and will give a light to determine standard reference range of weights of selected internal organs and also to find out relationship between internal organs' weight (IOW) and body mass index (BMI). This study was undertaken at RG Kar Medical College mortuary (morgue) for a period of one year. It is a descriptive study and the authors have tried to establish the appropriate relationships between BMI and organ weight through a crosssectional observation.

\section{Objectives}

1. To determine standard reference range of weights of selected internal organs.

2. To look for the sexual dimorphism among the selected organ weights. 
3. To find out relationship between internal organs weight (IOW) and body mass index (BMI).

\section{MATERIALS AND METHODS}

Study Area- Mortuary at RG Kar Medical College and Hospital, Kolkata-700004

\section{Study Population}

Male and Female dead bodies of Bengali Population (those persons who are born and brought up in the state of West Bengal and mother tongue is 'Bengali') of age group of 18 - 60 years, brought for autopsy examination during the study period.

\section{Inclusion Criteria}

a. Age group- adult dead bodies of 18 - 60 years,

b. Sex- both male and female,

c. Persons who were born and brought up in the state of West Bengal and whose mother tongue is 'Bengali.'

\section{Exclusion Criteria}

a. Any macropathologic change of internal organs that may have an effect on weight of organs.

b. History of prolonged hospital stay for any organ specific disease with any surgical or other invasive intervention prior to death and subsequent autopsy evaluation.

c. Any congenital and acquired deformities/ organ related syndromic sufferings (from external examination and enquiries about medical history- past and present from relations at mourners' room before autopsy).

d. Decomposed and mutilated bodies.

\section{Study Period}

One year- 1st March 2017 to 28th February 2018.

\section{Sample Size}

One hundred (100) dead bodies- 50 males and 50 females with due consideration of inclusion and exclusion criteria.

\section{Study Design}

Descriptive study.

\section{Study Technique}

1. Based on inclusion and exclusion criteria, 50 male and 50 female dead bodies, those were brought to the mortuary of RG Kar Medical College and Hospital.

2. Weight of whole body (off apparels) measured by standard electronic weighing machine with proper calibration every time.

3. Body length measured from top of head to tip of heel by measuring tape in centimetre.

4. Organs were removed following standard autopsy protocol and procedures, removal of attached tissue to make the organ bare minimum, drain out blood followed by thorough washing under running tap water and air dried followed by weighing in the same properly calibrated electronic weighing machine with reference weight of one kilogram.

\section{Statistical Tests and Analysis Used}

The values are given in means and SD. In cases where the distribution was not normal, the medians and IQR were calculated. Non-parametric Mann-Whitney U test was applied to identify the sexual dimorphism with respect to the selected organ weights. Kruskal-Wallis test was applied to establish the difference of median values with respect to the BMI. Nonparametric correlation was used to identify the type of correlation between the internal organ weight and BMI.

\section{RESULTS}

\begin{tabular}{|c|c|c|}
\hline Sex & Number of Cases & Percentage (\%) \\
\hline M & 50 & 50 \\
\hline F & 50 & 50 \\
\hline Total & 100 & 100 \\
\hline Table 1. Distribution of Study Population in relation to Sex \\
(M= Male, F= Female), $n=100$ \\
\hline
\end{tabular}

\begin{tabular}{|c|c|c|}
\hline BMI & Number of Cases & Percentage (\%) \\
\hline Underweight $(<18.5)$ & 05 & 5 \\
\hline Normal (18.5-22.9) & 58 & 58 \\
\hline Overweight (23-24.9) & 29 & 29 \\
\hline Pre-Obese (25-29.9) & 08 & 8 \\
\hline Obese $(>30)$ & 00 & 00 \\
\hline Total & 100 & 100 \\
\hline
\end{tabular}

\begin{tabular}{|c|c|c|c|}
\hline $\begin{array}{c}\text { Internal } \\
\text { Organs }\end{array}$ & $\begin{array}{c}\text { Mean Weight } \\
\text { (kgs) }\end{array}$ & $\begin{array}{c}\text { Standard } \\
\text { Error }\end{array}$ & $\begin{array}{c}\mathbf{9 5 \%} \\
\text { Confidence } \\
\text { Limit }\end{array}$ \\
\hline Brain & 1.215 & .009 & $1.197-1.233$ \\
\hline Heart & .291 & .004 & $.283-.299$ \\
\hline Liver & 1.280 & .015 & $1.250-1.310$ \\
\hline Spleen & .103 & .002 & $.099-.107$ \\
\hline \multicolumn{4}{|r}{ Table 3. Mean Internal Organs Weight amongst Male } \\
\hline
\end{tabular}

\begin{tabular}{|c|c|c|c|}
\hline $\begin{array}{c}\text { Internal } \\
\text { Organs }\end{array}$ & $\begin{array}{c}\text { Mean Weight } \\
\text { (kgs) }\end{array}$ & $\begin{array}{c}\text { Standard } \\
\text { Error }\end{array}$ & $\begin{array}{c}\mathbf{9 5 \%} \\
\text { Confidence } \\
\text { Limit }\end{array}$ \\
\hline Brain & 1.098 & .012 & $1.074-1.122$ \\
\hline Heart & .273 & .005 & $.263-.283$ \\
\hline Liver & 1.076 & .015 & $1.046-1.106$ \\
\hline Spleen & .091 & .003 & $.085-.097$ \\
\hline \multicolumn{4}{|r|}{ Table 4. Mean Internal Organs Weight amongst Female } \\
\hline
\end{tabular}

\begin{tabular}{|c|c|c|c|c|c|}
\hline $\begin{array}{c}\text { Internal } \\
\text { Organs }\end{array}$ & $\begin{array}{c}\text { Male } \\
\text { (kgs) }\end{array}$ & IQR & $\begin{array}{c}\text { Female } \\
\text { (kgs) }\end{array}$ & IQR & 'P' values \\
\hline Brain & 1.225 & 0.035 & 1.109 & 0.025 & $.001^{* *}$ \\
\hline Heart & 0.289 & 0.048 & 0.267 & 0.018 & $.003^{* *}$ \\
\hline Liver & 1.289 & 0.073 & 1.101 & 0.099 & $.001^{* *}$ \\
\hline Spleen & 0.098 & 0.027 & 0.086 & 0.053 & $.002^{* *}$ \\
\hline Table 5. Sex Distribution of Median Values of Internal \\
Organs Weight of Study Population and 'p' values by Non- \\
Parametric Mann-Whitney U Test \\
('P' value significant at<.05) \\
\hline
\end{tabular}




\begin{tabular}{|c|c|c|c|c|c|c|c|c|c|c|}
\hline $\begin{array}{c}\text { Internal } \\
\text { Organs }\end{array}$ & Underweight & IQR & Normal & IQR & Overweight & IQR & $\begin{array}{c}\text { Pre- } \\
\text { Obese }\end{array}$ & IQR & Obese & 'P' values \\
\hline Brain & 1.195 & 0.021 & 1.221 & 0.015 & 1.278 & 0.011 & 1.265 & 0.042 & - & .084 \\
\hline Heart & 0.208 & 0.080 & 0.283 & 0.045 & 0.303 & 0.026 & 0.357 & 0.035 & - & $.000^{* *}$ \\
\hline Liver & 1.123 & 0.150 & 1.213 & 0.089 & 1.339 & 0.102 & 1.408 & 0.102 & - & $.001^{* *}$ \\
\hline Spleen & 0.068 & 0.001 & 0.068 & 0.012 & 0.102 & 0.030 & 0.134 & 0.014 & - & $.000^{* *}$ \\
\hline
\end{tabular}

Table 6. Median Values distribution of Internal Organs Weight of Male population as per Categories of BMI and their ' $p$ ' values by Non-Parametric Kruskal-Wallis test ('p' value Significant at<.05)

\begin{tabular}{|c|c|c|c|c|c|c|c|c|c|c|}
\hline $\begin{array}{c}\text { Internal } \\
\text { Organs }\end{array}$ & $\begin{array}{c}\text { Under } \\
\text { Weight }\end{array}$ & IQR & Normal & IQR & Overweight & IQR & Pre-Obese & IQR & Obese & 'P' values \\
\hline Brain & 1.015 & 0.062 & 1.103 & 0.036 & 1.122 & 0.022 & 1.215 & 0.058 & - & .141 \\
\hline Heart & 0.234 & 0.002 & 0.267 & 0.085 & 0.268 & 0.078 & 0.292 & 0.046 & - & .219 \\
\hline Liver & 1.002 & 0.472 & 1.102 & 0.031 & 1.109 & 0.032 & 1.227 & 0.023 & - & .207 \\
\hline Spleen & 0.078 & 0.006 & 0.087 & 0.005 & 0.078 & 0.004 & 0.107 & 0.008 & - & .057 \\
\hline
\end{tabular}

Table 7. Median Values of Internal Organs Weight of Female population as per Categories of BMI and their 'p' values by NonParametric Kruskal-Wallis Test ('p' value Significant at <.05)

\begin{tabular}{|c|c|c|c|}
\hline Serial No. & Internal Organs & Correlation Coefficient Male (n= 50) & Correlation Coefficient Female (n= 50) \\
\hline 1 & Brain & $.274^{*}$ & $.285^{*}$ \\
\hline 2 & Heart & $.526^{* *}$ & $.204^{*}$ \\
\hline 3 & Liver & $.437^{* *}$ & $.217^{*}$ \\
\hline 4 & Spleen & $.468^{* *}$ & $.056^{*}$ \\
\hline \multicolumn{2}{|c|}{ Table 8. Non-Parametric Correlation (Spearman Rho) test result of 'BMI' vs. Internal Organ Weight in Male and Female } \\
\hline
\end{tabular}

**Statistically significant positive correlation; *Statistically significant positive correlation, but not very strong.

\section{DISCUSSION}

Of the 100 cases, 50 were males and 50 were females as shown in Table No. 2. Study population were divided according to BMI based on 'Asian Criteria 2003'(10) and it was observed that majority of the cases were having normal BMI (58 out of 100 $58 \%)$ followed by overweight (29\%), pre-obese $(8 \%)$ and underweight (5\%).

Result of descriptive statistical analysis as shown in Table No. 3 in the form of mean, standard deviation and $95 \%$ confidence interval (mean $+/-2 \mathrm{SD}$ ) of the male members of study population.

These values as shown in the Tables 3 and 4 are representative of mean organ weight of adult Bengali male and female strata respectively. These values in respect to male and female have similarities as mentioned in KSN Reddy's. "The essentials of Forensic Medicine and Toxicology" in respect to weight of heart. But however weight of brain and liver in this study population are not consistent with the findings of Dr. Reddy's and this difference may be due to differences in selected population, e.g. Eastern Indian vs. Southern Indian.(11) The values are also quite less as compared to the weight as mentioned as in BD Chaurasia's "Human Anatomy,"(12) except weight of heart. Again, these differences in this study may be due to differences in strata of selected population, e.g. Bengali vs. North Indian population, but not due to the difference in study technique e.g. medicolegal vs. anatomical dissection. However, these findings are as similar as mentioned as in "Normal Organ Weights in Indian Adults" 2006 by Kohli A et al.(13) It is also observed that females have lower organ weight as compared to male, which is due to different genetic configuration and smaller size as in females as compared to males. Other Indian study in this context as "A study of organ weight from persons who died in accident in Nagpur District of Maharashtra State," 2002 by Batra AK et al(14) showed similar results.

As mentioned in Table No. 5 the weight of Heart, Liver and Spleen were in significant positive linear correlation with calculated BMI in respect to male population, but only brain weight were in positive correlation with calculated BMI in female. This finding has similarities as that of Mathuramon $P$ et al study- "Correlation of Internal Organ weight with Body Weight and Length in Normal Thai Adults," 2009.(15)

\section{CONCLUSION}

It is noted from above discussion that this study is in agreement with some of the previous studies as mentioned and shows that BMI has a positive correlation with internal organ weight, especially in case of males. This study has unambiguously proved that the organ weights in case of males are significantly more than that of females. But organ weight in this adult Bengali male and female population in this study are quite lower as compared to the data as mentioned in standard textbook of Indian population. However, this present study needs more multicentric extensive analysis involving larger number of population, representative of all over the state of West Bengal inclusive of other strata of age groups including other important organs over a longer period of time to make it more sensitive.

\section{REFERENCES}

[1] Singh D, Sharma AK, Singh S, et al. Prediction of supine body length and body weight from brain weight of adults in Chandigarh zone of India. JIAFM 1998;20(3):53-9.

[2] Batra AK, Dongre AP and Mohanty AC. A study of organ weight from persons who died in accident in Nagpur district of Maharastra State. JFMT 2002;19(1):21-4. 
[3] Schiano TD, Bodian C, Schwartz M, et al. Accuracy and significance of computed tomographic scan assessment of hepatic volume in patients undergoing liver transplantation. Transplantation 2000;69(4):545-50.

[4] Ludwig J. Current methods of autopsy practice. $2^{\text {nd }}$ edn. Philadelphia: Saunders 1979:647-89.

[5] Sunderman FW, Boerner F. Normal values in clinical medicine. Philadelphia: Saunders 1949.

[6] Singh D, Bansal YS, Sreenivas M, et al. Weights of human organs at autopsy in Chandigarh zone of north-west India. JIAFM 2004;26(3):97-9.

[7] Tanna JA, Patel PN, Kalele SD. Relation between organ weights and body weight in adult population of Bhavnagar region-a post-mortem study. JIAFM 2011;33(1):57-9.

[8] Prakash C, Deopa D, Thakkar HK. Study of internal organ weight and its correlation to body weight in Kumaon region of Uttarakhand. JIAFM 2013;35(1):2931.

[9] Buchanan WJ, Daly FJ. Weight of human viscera in natives of Bengal. Indian Med Gaz 1902;37(2):56.
[10] Luisito OL, Roberto M. Comparison of body mass index based nutritional status using WHO criteria versus Asian criteria: report from the Philippines. Philspen Online Journal of Parenteral and Enteral Nutrition 2010-2012:1-8.

[11] Reddy KSN. The essentials of forensic medicine and toxicology. 34th edn. New Delhi: Jaypee Brothers Medical Publishers 2017:627-8.

[12] Chaurasia BD. Human anatomy. $5^{\text {th }}$ edn. Delhi: CBS Publishers \& Distributors Pvt. Ltd., 2010: pgs. 229, 243, 301, 309, 320, 307.

[13] Kohli A, Agarwal NK. Normal organs weights in Indian Adults. Medico Legal Update 2006.03-2006.06;6(2):34.

[14] Batra AK, Dongre AP, Mohanty AC. A study of organ weight from persons who died in accident in Nagpur district of Maharashtra state. JFMT 2002;19(1):21-4.

[15] Mathuramon P, Chirachariyavej T, Peonim AV, et al. Correlation of internal organ weight with body weight and length in normal Thai adults. J Med Assoc Thai 2009; $92(2): 250-8$. 